\title{
New and revised occurrences of rhynchonelliformean brachiopods from the middle Cambrian of the Iberian Chains, NE Spain
}

\author{
MiCHAL MERGL \& SAMUEL ZAMORA
}

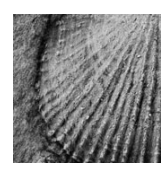

\begin{abstract}
New and revised occurrences of rhynchonelliformean brachiopods from the Languedocian (mid-late middle Cambrian) of the Iberian Chains are reported. The oldest assemblage corresponds to a level containing individuals of the new species Brahimorthis alvaroi and Nisusia sp. and is from the lower Languedocian Murero Formation. A younger assemblage is represented by Chilidorthis tecta from the Upper Languedocian Borobia and Torcas Formations. The geographic distribution and morphology of Brahimorthis, Chilidorthis and Bohemiella are reviewed and discussed. Moreover, evidence of the chilidium in Bohemiella and Chilidorthis and familial assignments of Brahimorthis, Saesorthis, Chilidorthis and Bohemiella are discussed. The new family Brahimorthidae fam. nov. is erected. • Key words: Brahimorthis, Bohemiella, Nisusia, Protorthida, Cambrian, Spain, Morocco, Czech Republic.
\end{abstract}

\begin{abstract}
MERGL, M. \& ZAMORA, S. 2012. New and revised occurrences of rhynchonelliformean brachiopods from the middle Cambrian of the Iberian Chains, NE Spain. Bulletin of Geosciences 87(3), 571-586 (8 figures). Czech Geological Survey, Prague. ISSN 1214-1119. Manuscript received December 7, 2011; accepted in revised form May 24, 2012; published online September 5, 2012; issued September 28, 2012.
\end{abstract}

Michal Mergl, Department of Biology, Faculty of Education, University of West Bohemia in Plzeň, Klatovská 51, 30619 Plzeň, Czech Republic; mmergl@kbi.zcu.cz•Samuel Zamora, Department of Palaeontology, The Natural History Museum, Cromwell Road, London SW75BD, UK; samuel@unizar.es

Apart from Trematobolus Matthew, 1893 and Nisusia Walcott, 1905, middle Cambrian rhynchonelliformean brachiopods are very rare in the Iberian Peninsula. They were first reported by de Verneuil \& Barrande in Prado et al. (1860), who described Orthisina (= Nisusia) vaticina from the lower middle Cambrian of the Cantabrian Mountains (North Spain). This description has been subsequently cited and revised several times (Walcott 1912, Sampelayo 1935, Wotte \& Mergl 2007). Havlíček \& Josopait (1972) described two further species, Chilidorthis tecta Havlíček 1972 and Brahimorthis cf. antiqua Havlíček, 1971, both from the Languedocian (late middle Cambrian) of the Iberian Chains (NE Spain). Liñán \& Mergl (2001) reported Jamesella sp. from the lower middle Cambrian of the Iberian Chains, and Gil Cid \& Mélou (1986) described new species assigned to Jamesella Walcott, 1905 and Yorkia Walcott, 1897 from Sierra Morena (South Spain). Rhynchonelliformean brachiopods from the middle Cambrian of the Iberian Peninsula are, in most cases, a minor component of a generally diverse fauna that includes trilobites, echinoderms, lingulate brachiopods and several molluscan groups (Liñán \& Gozalo 1986, Liñán \& Mergl 2001, Clausen \& Álvaro 2006, Wotte 2006, Zamora 2010). However, recent sampling in both classical and new localities from the Iberian Chains has provided new collections of rhynchonelliformeans. New specimens are compared with material from Morocco and Bohemia and the taxonomic positions of Brahimorthis and Chilidorthis are discussed.

\section{Geological and stratigraphical sites}

Within the Iberian Peninsula, the middle Cambrian (or Cambrian Series 3) is regionally subdivided into three stages named the Leonian, Caesaraugustan and Languedocian (Liñán et al. 1993, Álvaro \& Vizcaïno 1998). Correlation of these west Mediterranean stages with global series proposed by the ISCS is not yet confidentially established because the lack of key trilobite taxa and is under discussion (Peng \& Babcock 2011, Yuan et al. 2011). Base on chemostratigraphic data from Álvaro et al. (2008) the global Stage 5 probably corresponds with the Leonian, Caesaraugustan and part of the Languedocian stage while the two other Stages (Drumian and Guzhangian) probably fall within the Languedocian. For contrast other authors have been proposed the base of the Drumian within the Caesaraugustan stage base on poorly preserved trilobites which taxonomic assignment and utility in correlation are questionable (Gozalo et al. 

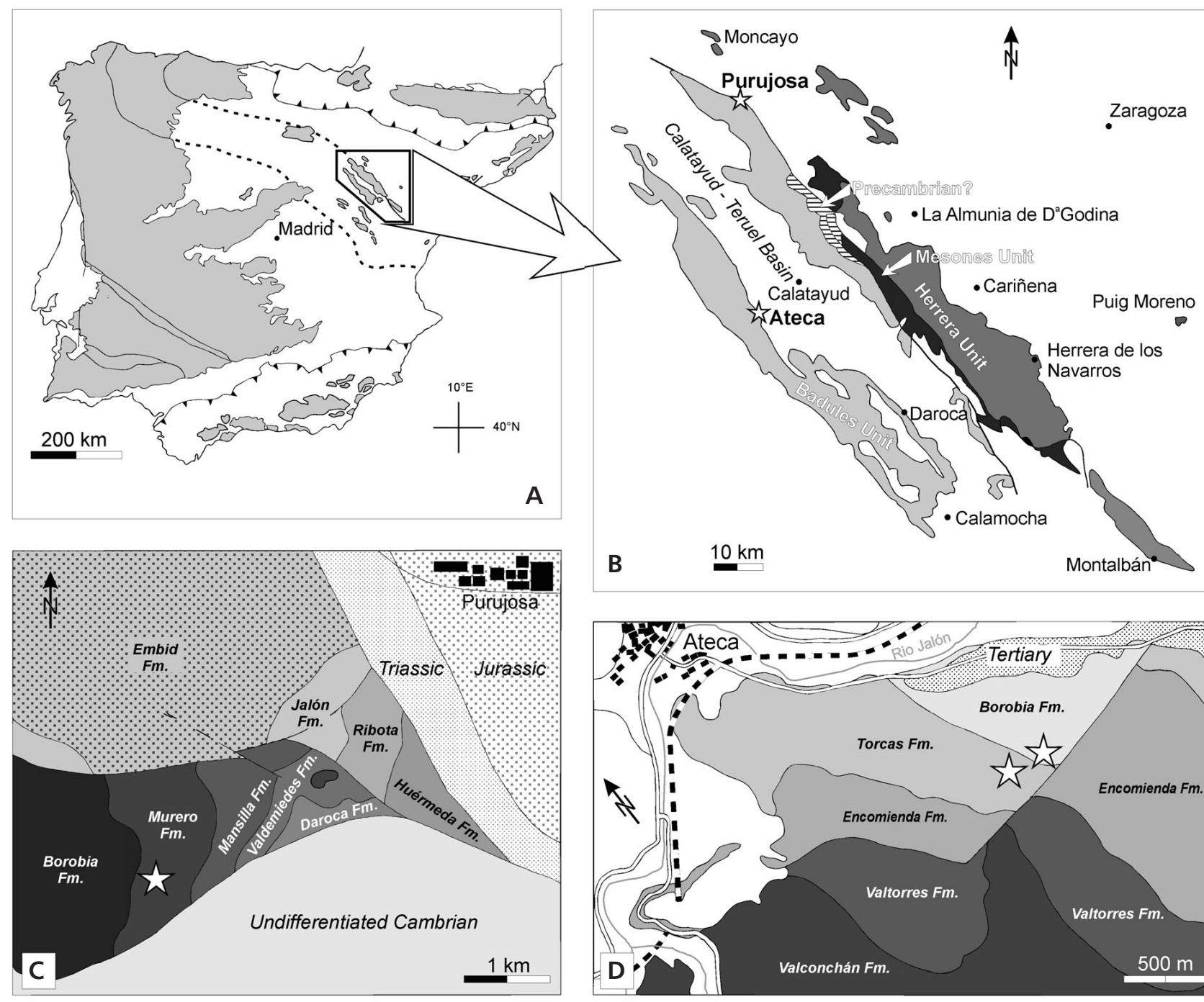

B $\quad \underline{10} \mathrm{~km}$

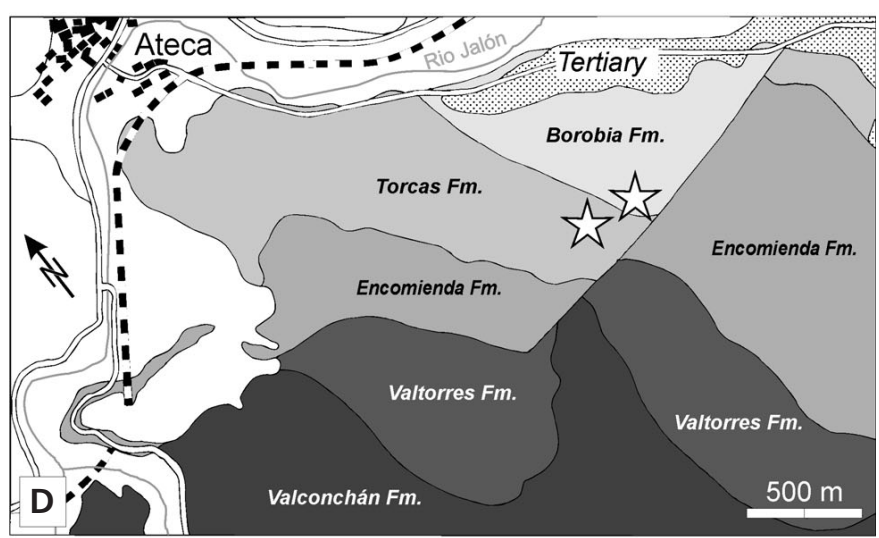

Figure 1. Geological settimg of sampled localities. - A - map of the Iberian Peninsula showing the position of the main pre-Hercynian outcrops. - B - detailed map of the Iberian Chains with the position of the studied localities. $\bullet \mathrm{C}-$ geological map of Purujosa with the position of the Pur3 section (after Zamora 2009). • D - geological map of Ateca with the position of level AT22 (after Josopait 1972).

2011). Middle Cambrian rhynchonelliformean brachiopods from the Iberian Peninsula have been reported from two different basins: the northern Cantabro-Ebroan Basin (including the Cantabrian Zone and the Iberian Chains) and the southern Ossa-Morena Basin (Ossa Morena Zone) (Fig. 1).

The faunas from the Cantabrian Zone come from the Láncara Formation (Leonian-Caesaraugustan), and $\mathrm{Ni}$ susia vaticina is a common component that sometimes occurs in great numbers (Prado et al. 1860, Sampelayo 1935, Wotte \& Mergl 2007). A few specimens of a new rhynchonelliformean taxon have been recovered from the lower Caesaraugustan Oville Formation in the Soto del Caso locality (Asturias), but this material awaits formal description. From the Iberian Chains, Trematobolus and $\mathrm{Ja}$ mesella occur in the Bilbilian-Leonian Valdemiedes Formation, where the former genus is an important component of the assemblages sometimes forming shell coquine levels.
A younger occurrence of a rhynchonelliformean in the Murero Formation is reported for the first time in this paper. This assemblage is known solely from the Purujosa 3 section in the northern part of the Iberian Chains (NE, Spain), 2 kilometres south of Purujosa village (Fig. 1). Specimens come from the uppermost part of the Murero Formation and were collected from a thin layer $(<1 \mathrm{~m}$ in thickness) of red lutites that is richly fossiliferous (Fig. 2). The associated fauna includes echinoderms - the edrioasteroid Protorophus hispanicus Zamora \& Smith, 2010, the cinctan Gyrocystis platessa Jaekel, 1918, the stylophoran Ceratocystis sp., two different cothurnocystids and the blastozoans Gogia gondi Ubaghs, 1987, Lichenoididae indet. and Dibrachicystis purujoensis Zamora \& Smith, 2012 (Zamora 2010; Zamora \& Smith 2010, 2012), polymerid trilobites - Eccaparadoxides pradoanus Verneuil \& Barrande (in Prado et al., 1960), Conocoryphe heberti 
Munier-Chalmas \& Bergeron in Bergeron, 1889, Solenopleuropsis thorali Sdzuy, 1958, S. marginata Sdzuy, 1958, S. verdiagana Sdzuy, 1958, agnostoids - Condylopyge sp., Pseudoperonopsis sallesi (Munier-Chalmas \& Bergeron in Bergeron, 1889 and Grandagnostus sp. (Esteve et al. 2011, Zamora et al. 2011), lingulate brachiopods and the orthacean brachiopods described in this paper. Esteve et al. (2011) interpreted this level as consisting of multiple obrution events deposited in off shore shelf environments. The trilobite Solenopleuropsis thorali indicates a lowermost Languedocian age (sensu Álvaro \& Vizcaïno 1998) for this level.

The Acon Group overlies the Murero Formation. This thick (more than $1000 \mathrm{~m}$ ) siliciclastic series has been subdivided into several different formations (Álvaro 1995), which range from the basal lower Languedocian Borobia Formation to the Furongian Valtorres Formation (Fig. 2). All the middle Cambrian faunas reported in Havlíček \& Josopait (1972) come from these levels. They described at least two middle Cambrian occurrences of rhynchonelliformeans. The lower level from the A1 unit (Borobia Formation sensu Álvaro 1995) provided individuals of Chilidorthis tecta Havlíček, 1971 associated with the trilobite Bailiella aff. levyi and is probably mid-late Languedocian in age. The second and younger assemblage comes from the A2 unit (Torcas Formation, sensu Álvaro 1995), and has provided, according to Havlíček \& Josopait (1972), the species Brahimorthis cf. antiqua associated with trilobites (Shergold \& Sdzuy 1991) that indicate an upper Languedocian age (sensu Álvaro \& Vizcaïno 1998), as well as specimens of the cinctan echinoderm Undatacinctus melendezi (Schroeder 1973, Zamora \& Álvaro 2010). Uncertainty concerning the morphology and taxonomic position of Chilidorthis was expressed by Williams \& Harper (2000). This, combined with uncertainty about the occurrence of Brahimorthis, are the main reasons for resampling these levels.

Other rhyncholleniformean brachiopods from the Iberian Chains have been collected in the Borobia, Torcas and Valtorres formations (Fig. 1), but the material is too poorly documented and rare to be described in detail at present. Lastly, two species of rhyncholleniformean brachiopods, Yorkia zafrensis Gil Cid \& Melou, 1986 and Jamesella iberica Gil Cid \& Melou, 1986, were described from the Ossa Morena Zone in South Spain (Zafra, Province of Badajoz). They were sampled from the Playon Beds, and the associated trilobite fauna (Gozalo et al. 1994) indicates that they are uppermost Caesaraugustan-mid Languedocian in age.

\section{Systematic palaeontology}

All figured specimens are housed in the palaeontological collections of the Museum of Dr. B. Horák in Rokycany, Czech Republic (3RO), in the Department of Biology, Uni-

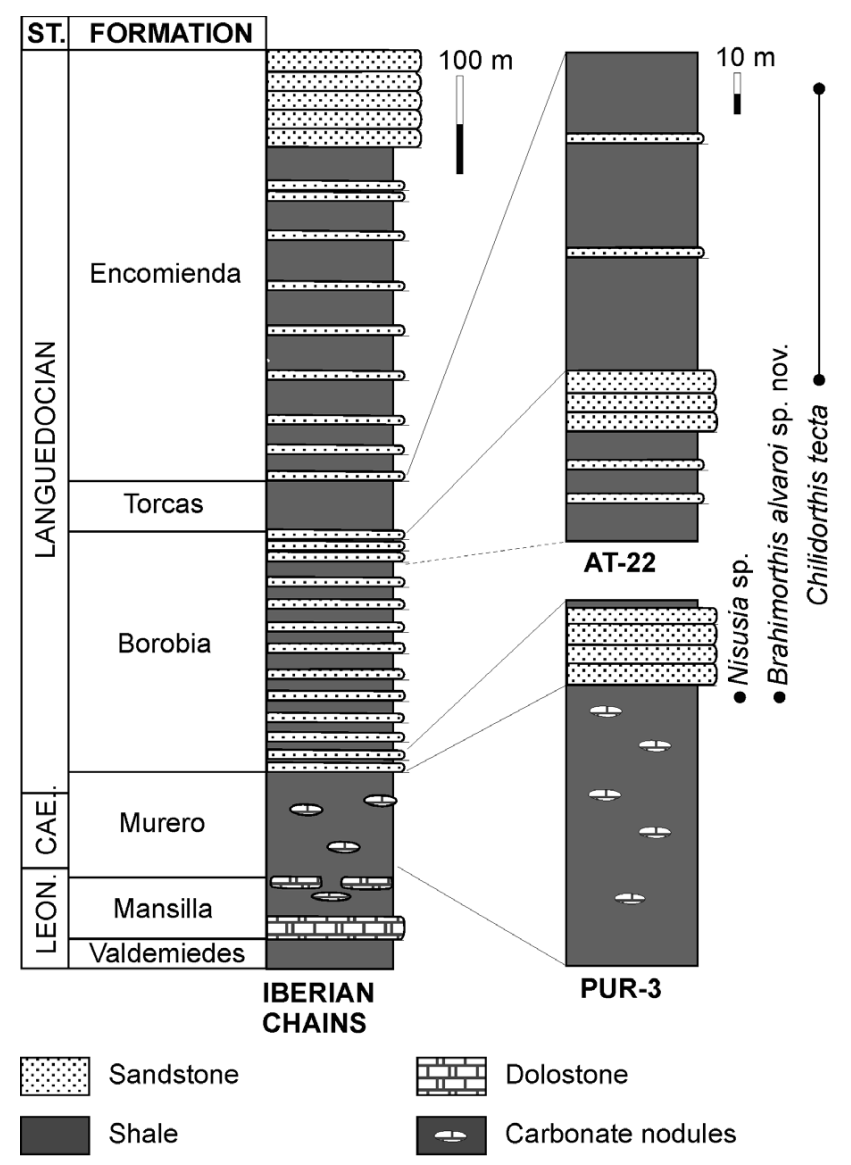

Figure 2. General stratigraphic section of Cambrian rocks in the Iberian Chains and detailed stratigraphy of Purujosa 3 and Ateca 22 sections showing the distribution of the studied rhynchonelliformean brachiopods.

versity of West Bohemia in Plzeň (PCZCU) and in the Museo Paleontológico de la Universidad de Zaragoza, Spain (MPZ).

Abbreviations. - $\mathrm{W}$ - width, $\mathrm{L}$ - length, $\mathrm{n}$ - number of specimens.

Order Kutorginida Kuhn, 1949

Superfamily Nisusoidea Walcott \& Schuchert, 1908

Family Nisusidae Walcott \& Schuchert, 1908

\section{Genus Nisusia Walcott, 1908}

Type species. - Orthisina festinata Billings, 1861; lower Cambrian; Vermont, USA.

Nisusia sp.

Figure 3 A-E, I, L

Material. - Four ventral valves (MPZ2009/547, 549, 550a, 552); and one dorsal valve (MPZ2009/550b). 
Description. - The shell is transversely subrectangular, with the L/W ratio ranging from 0.63 to $0.92(n=5)$; maximum width approximately midlength of the shell. The maximum width $(14 \mathrm{~mm})$ is estimated from the largest known specimen. The hinge line measures $85 \%$ of the maximum width. Cardinal extremities are obtuse to weakly alate (Fig. 3L).

Dorsal valve is gently convex, with a depressed median sector and prominent weakly curved apex. The maximum height is anterior to the apex. The dorsal pseudointerarea is steeply anacline. Dorsal interior is unknown.

Ventral valve is moderately convex in transverse profile and weakly convex along the shell axis. The apex is pointed, erect and pierced by a small foramen. A shallow sulcus is distinct from the midlength of the shell. The ventral interarea is high and apsacline, with a large and widely triangular delthyrium. Its sides subtend an angle of $90^{\circ}$. The pseudodeltidium is large and convex.

Ornamentation consists of numerous costellae originating from the apex. The size of costellae increases anteriorly. Primary costellae, numbering six to eight near the apex, are more prominent than intercalated ones. The largest preserved valve (Fig. 3L) has ca 70 costellae. Growth lines are distinct, wavy and irregularly spaced. The costellae on the ventral valve bear numerous low prostate spines; up to several in number on each primary costella, the spines are unknown on the dorsal valve. Preserved lengths of spines range from 1.2 to $1.5 \mathrm{~mm}$. The diameter of the internal canal of the large spines is $c a 200 \mu \mathrm{m}$.

The interior of ventral valve displays weak internal ribbing, with about 20 or more ribs in medium-sized shells. Teeth are large. Apical chamber is deep, anteriorly delimited by an indistinct triangular muscle field halved by a thin median ridge.

Remarks. - This is the first report of a nisusiid from the middle Cambrian of the Iberian Chains. The similar species Nisusia vaticina (Verneuil \& Barrande in de Prado et al., 1860) was originally described from the Cantabrian Zone of northwest Spain, but its correct taxonomic position was not proposed before the revision of Walcott (1912). Nisusia vaticina is common in reddish limestone (Upper Member) of the early middle Cambrian Láncara Formation (Wotte \& Mergl 2007). The shells described here are less transverse than those of $N$. vaticina, but there are only a few specimens to provide a detailed comparison with the Cantabrian species.

Occurrence. - Murero Formation, lower Languedocian; Purujosa, Iberian Chains, Spain.

Order Orthida Schuchert \& Cooper, 1932

Suborder Orthidina Schuchert \& Cooper, 1932

Superfamily Orthoidea Woodward, 1852
Brahimorthidae fam. nov.

Diagnosis. - Dorsibiconvex, strongly to weakly uniplicate, multicostellate and filose ornament, dental plates and spondylium absent; delthyrium and notothyrium open; ventral mantle canal system weakly impressed, with numerous radially disposed fine terminal canals along shell periphery; dorsal adductor field with four pairs of small radiating scars; notothyrium underlain by short transverse plate without distinct cardinal process; ventral muscle field of weakly defined small adductor scars anterior to the delthyrial chamber.

Remarks. - The new family is distinguished from the Protorthidae Schuchert \& Cooper, 1931 by the absence of a distinct free spondylium, but there are other features which link the Brahimorthidae with the Protorthoidea Schuchert \& Cooper, 1931. Adult shells of Brahimorthis lack an anterior extension of the transverse plate from the notothyrium and the cardinal process, which is characteristic of protorthids; however, juveniles of Brahimorthis (Fig. 4G) do show forward extensions of the free plate from the notothyrial chamber. The presence of this plate is assumed to be a plesiomorphic feature shared with the protorthids. Unlike other protorthoids that possess two pairs of scars, four pairs of scars are clearly impressed in the dorsal adductor field in Saesorthis (Geyer \& Mergl 1997, fig. 5). In Brahimorthis, only two pairs are clearly defined; this is likely the result of fusion of attachment sites into one field, although asymmetrical shapes of imprints are reminiscent of an originally more complex arrangement (Fig. 4H).

The morphology of Brahimorthis alvaroi is less derived than that of $B$. antiqua. The former species retains a distinct transverse plate anterior to the notothyrium in the adult stage and has a shortly mucronate hinge line. The latter feature is common in most protorthoid genera (see review by Williams \& Harper 2000) but may be seen also in some early orthoids. The Brahimorthidae is referred to Orthida due the lack of dental ridges uniting with free spondylium, but features mentioned above indicate some affinity to Protorthidae.

Genera assigned. - Brahimorthis Havlíček, 1971: middle Cambrian; Morocco, Spain, Bohemia, Czech Republic; Saesorthis Geyer \& Mergl, 1997: middle Cambrian; Morocco; ?Cymbricia Roberts \& Jell, 1990: middle Cambrian; Morocco.

\section{Genus Brahimorthis Havlíček, 1971}

Type species. - Brahimorthis antiqua Havlíček, 1971; middle Cambrian; Morocco. 

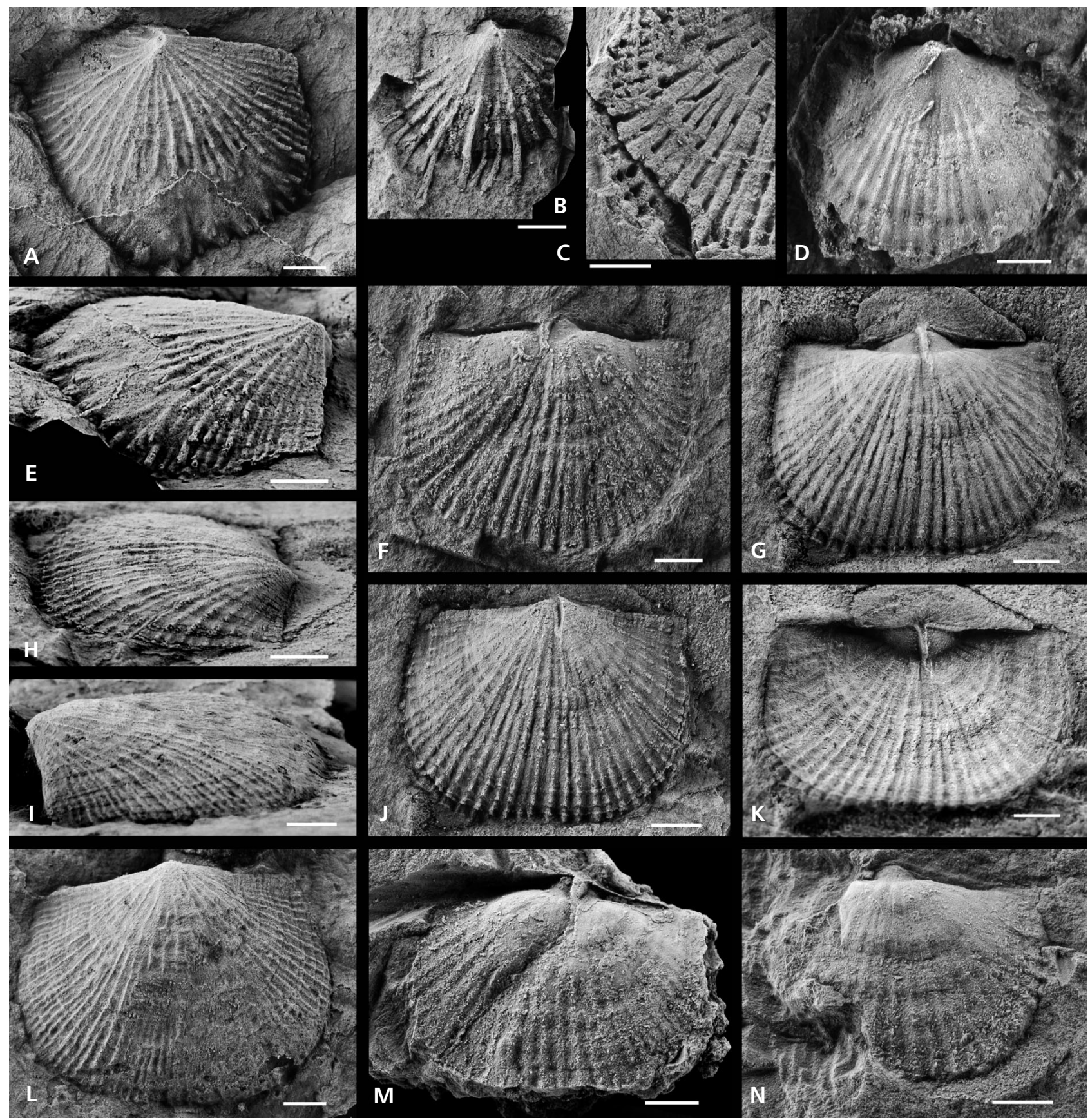

Figure 3. A-E, I, L-Nisusia sp. Age and locality: middle Cambrian, lower Languedocian, Murero Formation; Spain, Iberian Chains, Purujosa. Bar equals $2 \mathrm{~mm}$. A , C, E - ventral valve, latex cast of external mould (A, E) and fragment of shell (C), detail of spines on the external mould, and oblique lateral view, MPZ2009/550a, 547. • B - ventral valve, latex cast of external mould, MPZ2009/549. • D - internal mould of ventral valve, MPZ2009/552. • I, L - dorsal valve, latex cast of exterior in lateral and ventral views, MPZ2009/550b. • F-H, J, K, M, N - Brahimorthis alvaroi sp. nov. Age and locality: middle Cambrian, lower Languedocian, Murero Formation; Spain, Iberian Chains, Purujosa. Bar equals $2 \mathrm{~mm}$. $\mathrm{F}-\mathrm{ventral}$ valve, internal mould, MPZ2009/551. • G, H, J, K - holotype, dorsal valve, internal mould, oblique lateral view to latex cast of exterior, latex cast of exterior, and internal mould in slightly posterior view, MPZ2009/554a, b. • M - ventral valve, internal mould, MPZ2009/556, N - dorsal valve, internal mould, MPZ2009/545.

Diagnosis. - See Havlíček (1971).

Remarks. - In his original description, Havlíček (1971) compared Brahimorthis to Nisusia Walcott, 1905, Bohemi- ella Schuchert \& Cooper, 1931 and Jamesella Walcott, 1905. However, these genera have recently been assigned to different classes or orders. In 1977, Havlíček erected the new family Bohemiellidae. He included Brahimorthis, 
Chilidorthis Havlíček, 1972, Diraphora Bell, 1941, Oligomys Schuchert \& Cooper, 1931, Pompeckium Havlíček, 1970, Wimanella Walcott, 1908, Shiragia Kobayashi, 1935 and questionably, Ocnerorthis Bell, 1941 in this family. The systematic position of Brahimorthis and the concept of the Protorthacea were discussed by Geyer \& Mergl (1997). They left Brahimorthis in the Bohemiellidae, although they expressed the opinion of a close evolutionary affinity of this genus with Saesorthis Geyer \& Mergl, 1997, which they referred to the Protorthidae.

In the revised edition of Treatise on Invertebrate Palaeontology, Williams \& Harper (2000) referred Brahimorthis to the Eoorthidae Walcott, 1908 within the Plectorthoidea. These authors also rejected the attribution of Pompeckium and Ocnerorthis to the Bohemiellidae. The rejection of Brahimorthis from the family Bohemiellidae seems reasonable. The bohemiellid genera have short brachiophores and simple and distinct cardinal process; both characters are absent in Brahimorthis. The absence of the dental plates is a common feature in many Cambrian families. Williams \& Harper (2000) also noted the ramicostellate and filate ornament of Brahimorthis (Fig. 4E, F). Other eoorthid genera have a quite different ornament, varying from costellate to fascicostellate, and often having superimposed capillae. There are a few strange eoorthids known from the middle and late Cambrian (see Williams \& Harper 2000) which placement within the eoorthids is questionable.

Brahimorthis shows a peculiar arrangement of the delthyrial chamber and ventral muscle field, which is different from Bohemiella. A triangular, transversely striated field is visible in the apical part of the delthyrial chamber (Fig. 4J, R). This small triangular field, originally interpreted by Havlíček (1971) as the ventral muscle field, is herein reinterpreted as an undivided scar of the diductor muscles. The axial deepening of this scar and anterior inflexion of growth striations are likely due the axially accommodated pedicle at the apical part of the delthyrial chamber. The bipartite callosity placed anterior to the delthyrial chamber (Fig. 4J, K, R; see also Geyer \& Mergl 1997, figs 9-3, 9-8) probably borders two pairs of small adductor scars. The steep lateral sides of the delthyrial chamber display thin triangular impressions, which are about two times longer than the suggested diductor scar; these imprints are interpreted newly as the adjustor scars. The suggested placement of muscle imprints on the shell interior is shown in Fig. 5.

This interpretation of scars is based on the functional morphology of the muscle system. The dorsal valve floor has two distinct, posteriorly situated pairs of adductor scars. If the adductors were attached only in the apical part of the delthyrial chamber of the ventral valve (= striated area interpreted herein as the diductor scar), then their traction would have led to opening instead of closing of the shell. The attachment site of the adductors on the ventral valve should be somewhat anterior to the hinge line in order to facilitate rotation along the hinge and the closure of the shell. This could be achieved by an anteriorly extended transverse plate projecting from the delthyrial chamber (as in protorthids) or by the anterior shift of the adductor attachment sites on the valve floor (as in orthids). Brahimorthis does not show a proper transverse plate, as developed in protorthids. Small but deep scars of the adductor muscles are therefore placed just in front the delthyrial chamber, below the steep slope of the posterior valve floor.

A similarly unusual placement of the ventral adductor scars is known from the middle Cambrian genus Cymbricia Roberts \& Jell, 1990. In this genus, the adductor scars are inserted in a heart-shaped pit located in anteriomedial position, and the diductor scars occupy the delthyrial chamber. The attachment site of the diductors in the dorsal valve of Brahimorthis is typically orthoid. The posterior part of the notothyrial chamber has a striated surface lacking any sign of the cardinal process. The transverse striation probably represents the wrinkled surface of the diductor site.

The disposition of the pallial markings in Brahimorthis is poorly known. One of the internal moulds of the topotypic specimens shows a weakly divergent proximal part of the ventral vascula media. The dorsal pallial markings are obscure.

\section{Brahimorthis antiqua Havlíček, 1971}

Figures 4A-V, 5

1971 Brahimorthis antiqua sp. n. Havlíček, p. 29, pl. 1, figs $1-10$.

Figure 4. Brahimorthis antiqua Havlíček, 1971. Age and locality: middle Cambrian, Jbel Wawrmast Formation; Morocco, Hassi Brahim section, sampling horizon D 1887. Bar equals $2 \mathrm{~mm}$. $\bullet \mathrm{A}, \mathrm{B}, \mathrm{D}-\mathrm{F}$ - dorsal valve, latex cast of exterior, slighly oblique view to cardinal extremity (B), oblique lateral view (D), detail of ornamentation (E), and detail of filose ornament (F), RO C805. C - dorsal valve, slighly oblique view to cardinal extremity, RO C802. $\cdot \mathrm{G}$ - very small ventral valve, internal mould, RO C $801 \cdot \bullet \mathrm{H}$ - small dorsal valve, internal mould, RO C806. $\bullet \mathrm{I}, \mathrm{P}, \mathrm{T}-$ dorsal valve internal mould: detail of internal crenulation (I), internal moud (P), and detail of notothyrial chamber (T), RO C799. $\bullet J, K, R$ - ventral valve internal mould: detail of delthyrial chamber in oblique view (J), internal mould (K), and detail of delthyrial chamber $(\mathrm{R}), \mathrm{RO} \mathrm{C} 810 \cdot \bullet \mathrm{L}, \mathrm{V}-$ dorsal valve internal mould, and latex cast showing notothyrial chamber and adductor scars, RO C796b. $\bullet \mathrm{M}$ - dorsal valve internal moud, RO C804. $\bullet \mathrm{N}, \mathrm{S}-$ ventral valve internal mould and its latex cast, RO C796a. $\bullet \mathrm{O}, \mathrm{Q}-$ dorsal valve internal mould and detail of notothyrial chamber, RO C $812 \cdot \bullet \mathrm{U}-$ dorsal valve internal mould, detail of notothyrial chamber, RO C798. 
Michal Mergl \& Samuel Zamora $•$ Rhynchonelliformean brachiopods from the middle Cambrian of Spain

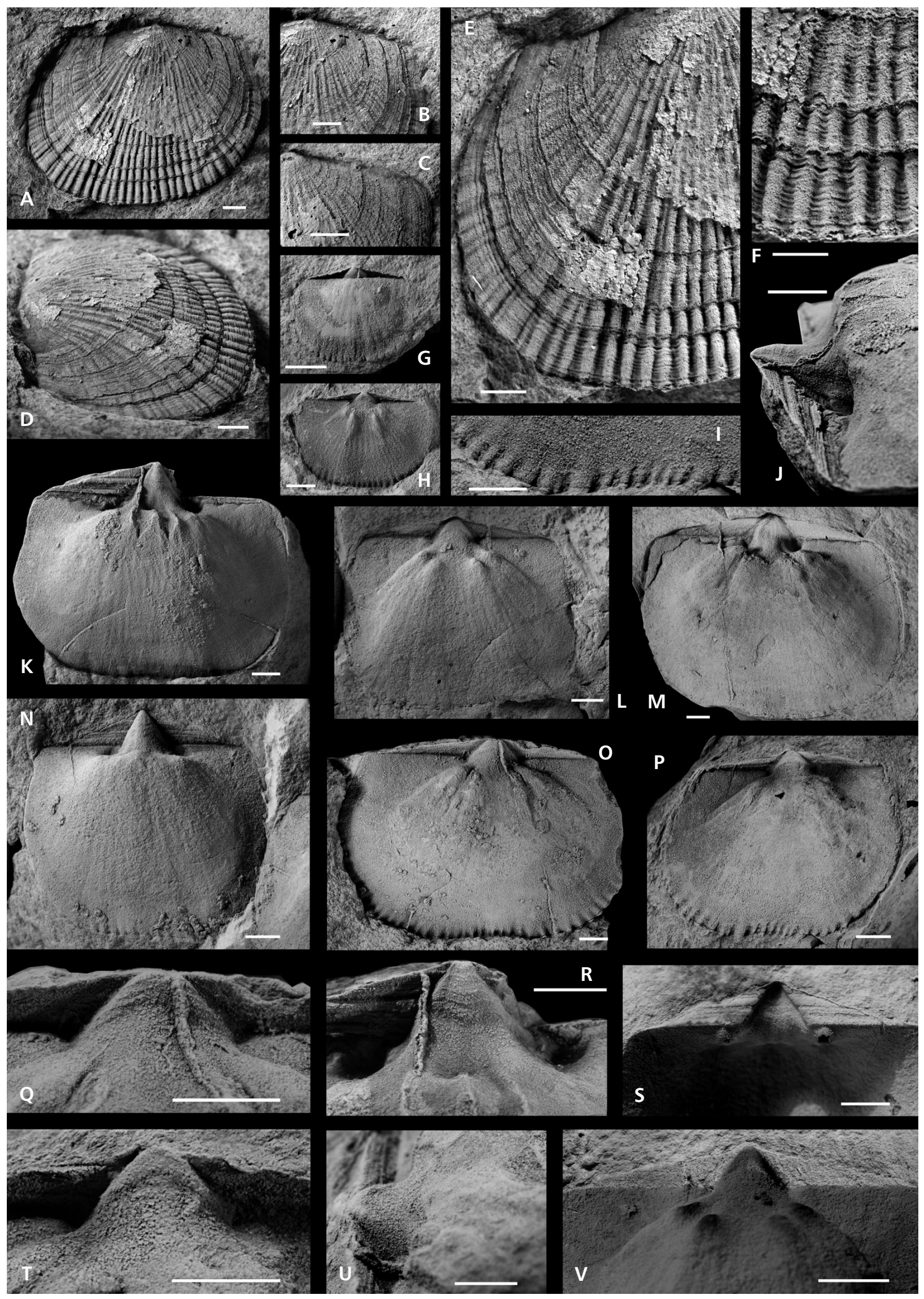




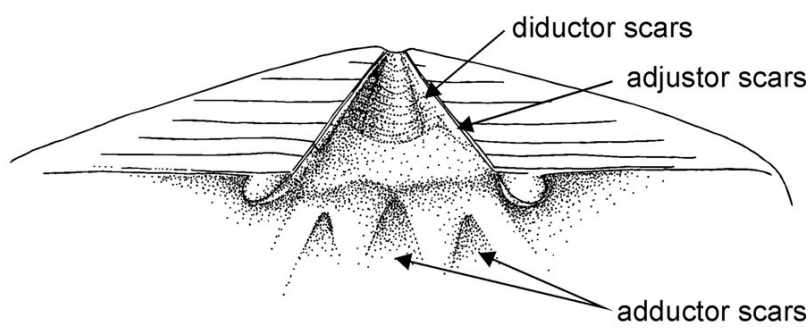

A

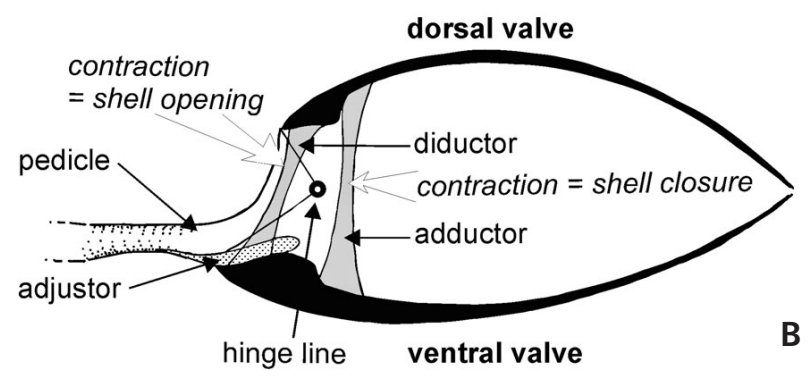

Figure 5. Brahimorthis antiqua Havlíček, 1971. Ventral valve interior with sites of muscle scars (A) and diagrammatical reconstruction of shell muscle system (B) along the shell axis; adductors are located anterior to the axis of rotation (= circle).

1983 Brahimorthis antiqua Havlíček, 1971. - Mergl, p. 340 , pl. 1, figs 2,3 .

1997 Brahimorthis antiqua Havlíček, 1971. - Geyer \& Mergl, p. 807, figs 8.16, 9.2-9.10, 9.12, 9.13.

Remarks. - This species were described by Havlíček (1971) and Geyer \& Mergl (1997). Specimens of Brahimorthis n. sp. A are probably conspecific with B. antiqua because the differences noted by Geyer \& Mergl (1997) fall within the range of variability now observed in $B$. antiqua.

Distribution. - Middle part of middle Cambrian, Jbel Wawrmast Formation, layers with Badulesia tenera (lower Caesaraugustan), Hassi Brahim section, Anti-Atlas, Morocco.

\section{Brahimorthis pompeckiana Havlíček, 1977} Figure 6A-K

1977 Brahimorthis pompeckiana sp. n. Havlíček, p. 31, pl. 2, figs $15-19$.

Material. - Two incomplete ventral valves (3RO $21307=$ original number VH 1400a, 3 RO $21311=$ VH 1400e), and three almost complete dorsal valves (3RO $21308=\mathrm{VH}$ $1400 \mathrm{~b}, 3 \mathrm{RO} 21309=\mathrm{VH} 1400 \mathrm{c}, 3 \mathrm{RO} 21310=\mathrm{VH} 1400 \mathrm{~d})$.

Description. - See Havlíček (1977) for a complete description of this taxon.
Remarks. - Havlíček (1977) described and figured rare material of Brahimorthis from the Jince Formation (middle Cambrian) of Bohemia. Up to now, only three incomplete dorsal and two ventral valves have been collected. Havlíček noted that is rather difficult to compare B. pompeckiana with the type species due to the different modes of preservation. All known shells of $B$. pompeckiana were collected in coarse sandstones and many features are therefore poorly preserved. However, the general morphology of the shell is consistent with attribution to Brahimorthis. Havlíček (1977) used the ornamentation for discrimination of both species. Costellae in B. pompeckiana are subangular and separated by wider interspaces, while costellae of $B$. antiqua are wider and separated by narrow interspaces. In addition to this feature, the ventral interarea of B. pompeckiana is lower and less steep than that of $B$. antiqua. The dorsal valve of $B$. pompeckiana has a more convex axial profile with a less flattened anterior. This feature is not the result of differential preservation because all dorsal valves of B. pompeckiana, unlike valves of $B$. antiqua, lack this flattening. All shells have been collected from coarse sandstone and the associated fauna is rare and poorly represented by indeterminable fragments of large lingulate brachiopods.

Occurrence. - Middle part of middle Cambrian, Jince Formation, Eccaparadoxides pusillus Zone; Velcí, Př́bramJince Basin, Czech Republic.

\section{Brahimorthis alvaroi sp. nov.}

Figures 3F-H, J, K, M, N

Holotype. - Dorsal valve figured on Fig. 3G, H, J, K (MPZ2009/545, 554, 556).

Paratype. - Ventral valve figured on Fig. 3F (MPZ2009/551).

Type horizon. - Pur3 section, level 10, top of the Murero Formation, lower Languedocian.

Type locality. - Purujosa, Iberian Chains, Spain.

Etymology. - In honour of Dr. Javier Álvaro for his contribution to the advancement of knowledge on the Languedocian Stage in the Mediterranean area and his help sampling in the studied areas.

Material. - Three dorsal and thee ventral valves MPZ2009/545, 551, 553, 554, 555, 556.

Diagnosis. - Brahimorthis with short alate cardinal extremities, distinct costellation on posterolateral flanks, and 


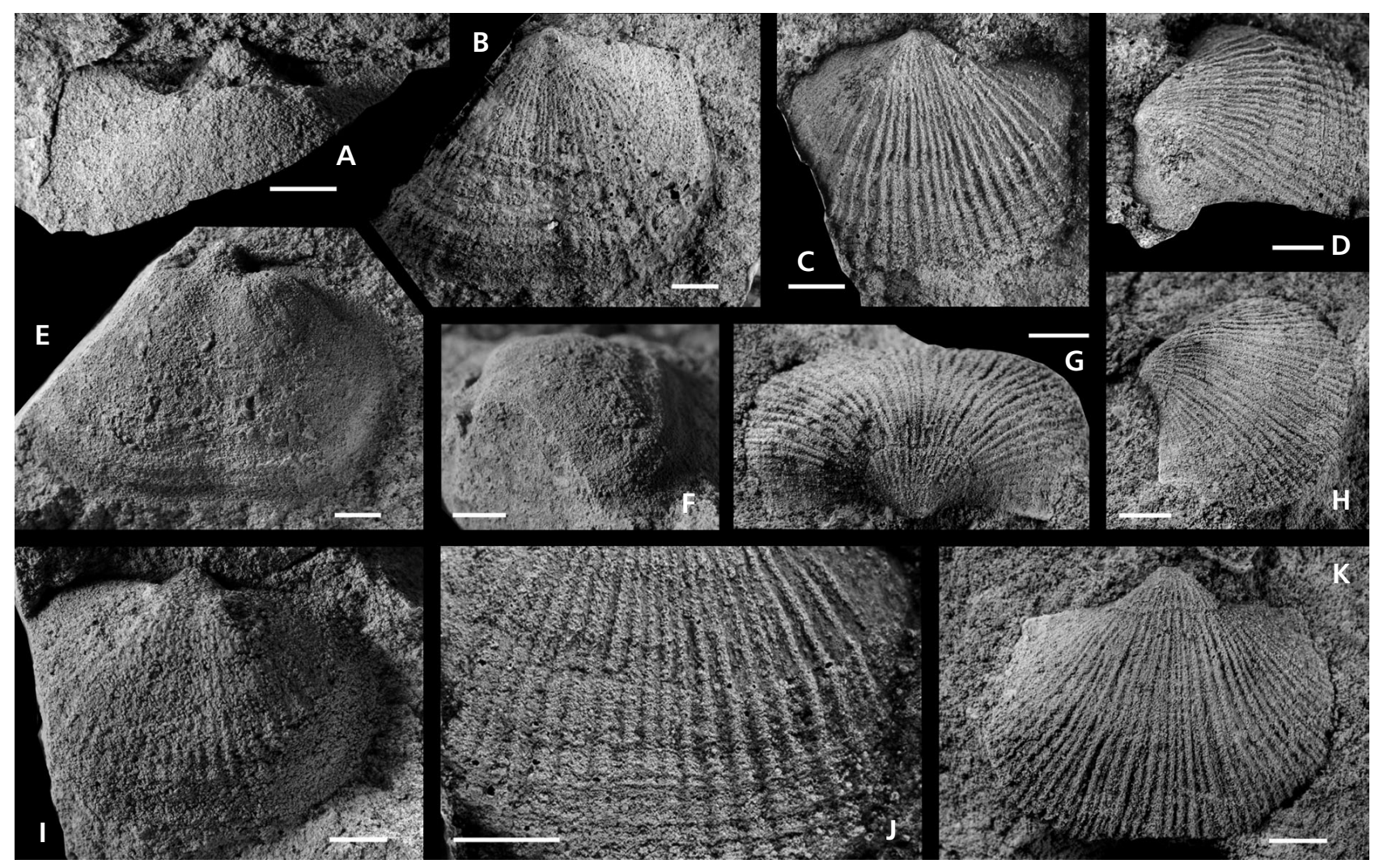

Figure 6. Brahimorthis pompeckiana Havlíček, 1977. Age and locality: middle Cambrian, Jince Formation, Eccaparadoxides pusillus Zone; Czech Republic, Př́bram-Jince Basin, Velcí. Bar equals $2 \mathrm{~mm}$. A - internal mould of ventral valve, 3RO 21311. • B, E, F - dorsal valve, latex cast of exterior, internal mould, and oblique lateral view to internal mould, $3 \mathrm{RO} 21310$. C, D, I, J - dorsal valve, latex cast of exterior, the same on oblique lateral view, internal mould and detail of ornamentation, $3 \mathrm{RO} 21309 . \bullet \mathrm{G}, \mathrm{H}, \mathrm{K}$ - ventral valve, latex cast of exterior in oblique posterior, oblique lateral, and ventral views, 3RO 21307.

broadly triangular notothyrial chamber; no median ridge in dorsal valve floor.

Description. - The shell is biconvex, subrectangular in outline and $15 \mathrm{~mm}$ wide in the largest known specimen. The maximum width is at the mid part of the valve.

The dorsal valve has acute cardinal extremities extended into short flattened alae. Flanks are evenly curved. The anterior margin is weakly curved. Transverse profile is gently convex. Axial profile is evenly convex, having the maximum height at the posterior one-third. A weakly defined sulcus is distinct from about the posterior third of the valve. The dorsal interarea is anacline, low and with a broadly triangular notothyrium. The sides of notothyrium subtend at an angle of $120^{\circ}$. The dorsal interior shows a broadly triangular notothyrial chamber. The cardinal process is absent, but the area of attachment of the diductors is marked by a fine arcuate striation. The dorsal adductor field consists of two pairs of small subcircular muscle scars placed anterior and anterolateral to the notothyrial chamber. In addition, there is a weakly impressed third pair of scars lateral to the notothyrial chamber. A fine and short median ridge is present.
The ventral valve is gently convex with a steeply apsacline interarea. The ventral muscle field is small and restricted to the delthyrial chamber and the surface of the short convex plate weakly raised above the valve floor.

The ornamentation is costellate consisting of subangular uniformly-sized costella. Primary costellae are distinct from the apex. Interspaces are wider than costellae. New costellae are rare, originating by implantation. There are some 40 costellae in the measured specimens (Fig. 3J). Growth lines are of uneven size, some approaching short growth lamellae.

Remarks. - The new species differs from Brahimorthis antiqua Havlíček, 1971 in the coarser costellation, the weaker shell convexity in the posterior third of shell, the lower ventral interarea, the absence of the dorsal median ridge and the wider notothyrial chamber. However, the main difference concerns the shell outline: the cardinal extremities of B. antiqua and B. pompeckiana are obtuse while in B. alvaroi are flattened and extended into short alae, which form an acute angle. This feature is clear in all specimens of B. alvaroi despite some shell compression in shale. 
Occurrence. - Murero Formation, Languedocian; Purujosa, Iberian Chains, Spain.

Family Bohemiellidae Havlíček, 1977

Remarks. - When defining the Bohemiellidae, Havlíček (1977) discussed several unique features of the family. The absence of dental plates is one typical feature. Havlíček assigned nine genera to the family including Chilidorthis Havlíček \& Josopait, 1972. Williams \& Harper (2000) assigned seven genera to the Bohemiellidae and expressed some doubts (based on the poor state of preservation of the original material) about the familiar assignment of Chilidorthis. Bohemiellids are a group including (with the possible exception of Murrinyinella Kruse, 1990) planoconvex, subquadrate and costelate middle Cambrian orthoids. Presence of the chilidium or chilidial plates might be another significant feature of the family, but fine details of shell morphology are well known only in a few genera of Bohemiellidae.

\section{Chilidorthis Havlíček \& Josopait, 1972}

Type species. - Chilidorthis tecta Havlíček \& Josopait, 1972; middle Cambrian, Spain.

Remarks. - In the diagnosis of Chilidorthis, the presence of a large convex chilidium is the unique character that distinguishes this genus from other members of the Bohemiellidae. Based on this feature, Williams \& Harper (2000) questioned the familiar assignment of this genus, but they also commented the poor state of preservation of C. tecta. Chilidorthis shows a large convex chilidium (Fig. 7G, H). Re-examination of Bohemiella romingeri Barrande, 1931 reveals the presence of a small, planar but distinct chilidium apically closing the notothyrium (Fig. 7U) and thin low chilidial plates extending from the chilidium and bordering the notothyrium.

Previously, Havlíček (1977) noted that the cardinal process of Bohemiella ranges from a thin setal plate to a broad ridge-like structure resting on a low notothyrial platform (Fig. 7S, T). The cardinal process has a distinct median separating ridge and lateral myophore ridges. There is no striated surface on the myophore in Bohemiella. Similarly broadly ridge-like cardinal process with a low median ridge and lateral myophore ridges are present in Chilidorthis (Fig. 7F, G). The notothyrial platform in Bohemiella and Chilidorthis extends forwards into a broad and low median ridge. The ventral muscle field of Chilidorthis is subtriangular, confined to a deep delthyrial chamber. It is clearly tripartite, with narrowly triangular diductor scars extending forwards from the delthyrial chamber and a narrower and shorter adductor track resting on an anteriorly elevated platform (Fig. 7M, Q). The shape of the ventral muscle field and the absence of dental plates also are other features shared with Bohemiella.

Due to their preservation in sandstones, the arrangement of the vascular system is not well known in Chilidorthis. It is of a saccate type in the ventral valve, and probably has a digitate or lemniscate condition in the dorsal valve. Weakly divergent vascula media divide at about the midlength of the ventral valve and continue by arcuate canals splitting into numerous vascula terminalia normal to valve margins (Fig. 7J, O-Q). The same saccate condition is known in the ventral valve of Bohemiella (see Havlíček 1977; pl. 2, figs 3, 4, 11). The vascular system in the dorsal valve of Chilidorthis is less known. There are undoubted arcuate vascula media, but imprints of vascula myaria are poorly preserved and vascula genitalia are not discernible (Fig. 7N, 8A). The same system is present in the dorsal valve of Bohemiella; re-examination shows finely preserved imprints of the vascula media, vascula myaria and vascula genitalia (Fig. 7S, 8B).

\section{Chilidorthis tecta Havlíček \& Josopait, 1972} Figures 7A-R, 8A

1972 Chilidorthis tecta Havlíček \& Josopait, p. 343, figs $4: 5,5: 1-8$.

?1972 Brahimorthis cf. antiqua Havlíček, 1971, p. 346.

Figure 7. Chilidorthis tecta Havlíček \& Josopait, 1972. Age and locality: middle Cambrian, Borobia Formation upper Languedocian; Spain, Iberian Chains, Valtorres, locality AT-22. Bar equals $2 \mathrm{~mm}$. A, F- medium-sized dorsal valve and detail of its cardinalia, internal mould, MPZ 2011/79. • B, Gdorsal valve, internal mould and latex cast its cardinalia, MPZ 2011/80. $\bullet$ C - dorsal valve, internal mould, MPZ 2011/81. $\bullet$ D, H - large dorsal valve and latex cast of cardinalia showing the chilidium, internal mould, MPZ 2011/82. • E - dorsal valve, deformed internal mould, MPZ 2011/83. $\bullet$ I - medium-sized dorsal valve, internal mould showing median ridge and subperipheral rim, MPZ 2011/84. • J, O - ventral valve, internal mould showing subperipheral rim, MPZ 2011/85. • K - ventral valve, internal mould, MPZ 2011/86. • L - medium-sized dorsal valve, internal mould showing well preserved brachiophore, MPZ 2011/87. • M - fragment of ventral valve, internal mould showing ventral muscle field, MPZ 2011/88. $\bullet$ - large dorsal valve, internal mould, MPZ 2011/89. • P - ventral valve, internal mould showing pallial markings, MPZ 2011/90. • Q - ventral valve, internal mould showing ventral muscle field and proximal vascula media, MPZ 2011/91. • R - latex cast of dorsal valve exterior, MPZ 2011/92. Bohemiella romingeri (Barrande, 1848). Age and locality: middle Cambrian, Buchava Formation, Skryje Member, Eccaparadoxides pusillus Zone; Czech Republic, Skryje-Týřovice Basin, Biskoupky. Bar equals $2 \mathrm{~mm}$. $\bullet \mathrm{S}$ - medium-sized dorsal valve, internal mould showing adductor scars, PCZCU 1806 . $\bullet$ T - dorsal valve, internal mould of cardinalia, PCZCU 1807. • U - dorsal valve, external mould showing the chilidium, PCZCU 1808. 
Michal Mergl \& Samuel Zamora $•$ Rhynchonelliformean brachiopods from the middle Cambrian of Spain

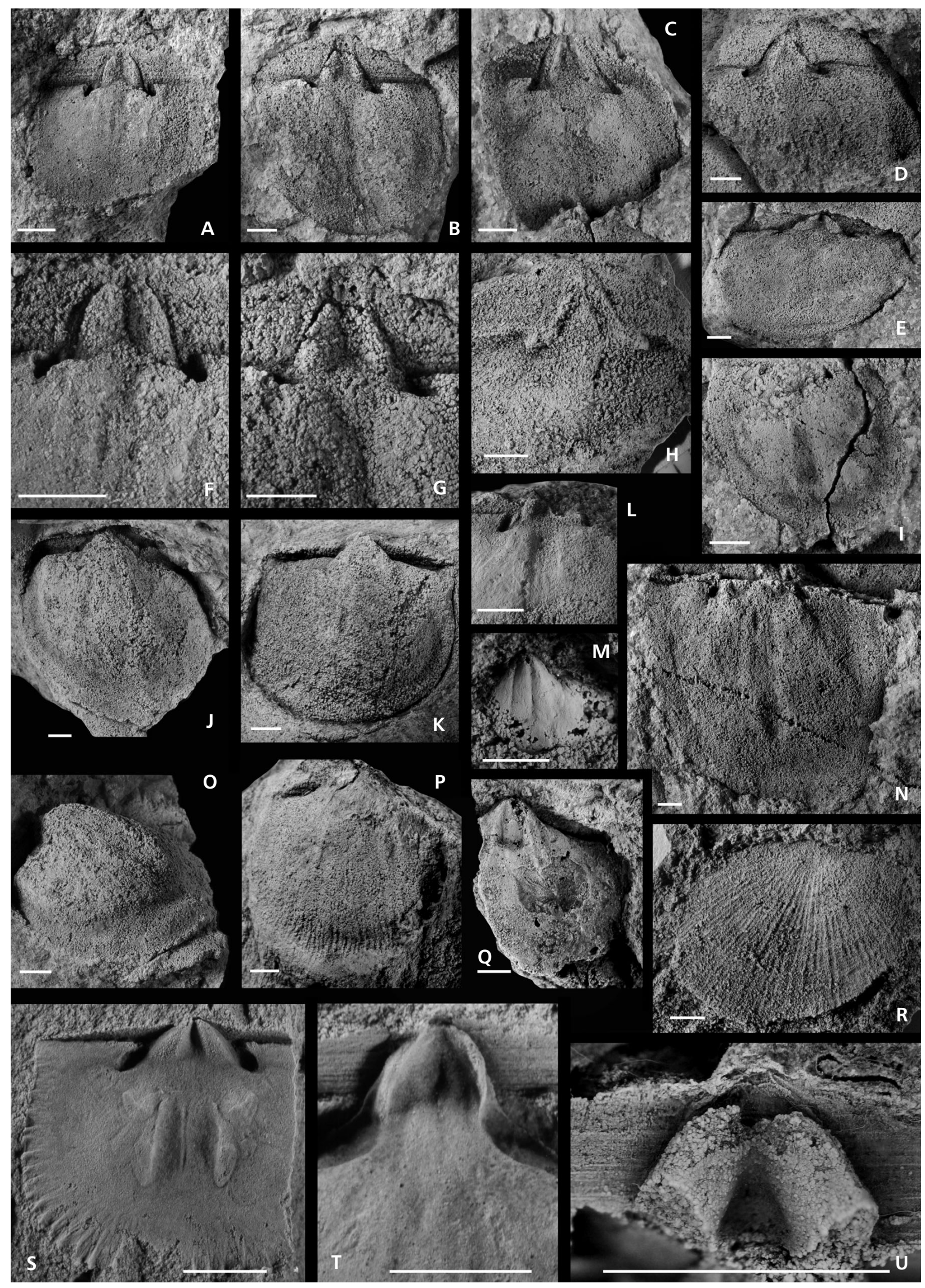


Material. - Several dozen ventral and dorsal valves, mostly poorly preserved in coarse sandstone. Sixteen specimens figured (MPZ 2011/79-95) and about fifty more specimens.

Emended description. - The shell is planoconvex to weakly concavo-convex, $20 \mathrm{~mm}$ wide and thick-walled especially along the hinge line, which has a rectimarginate commissure.

The dorsal valve is planar, almost flat with a broadly subrectangular to transversely semielliptical outline. The maximum width is at hinge line. Cardinal extremities are rectangular to gently alate. A narrow, shallow sulcus may be developed in the posterior third of the valve, becoming obscure anteriorly. The dorsal interarea is low anacline, high, flat and covered by distinct growth striations of uniform size. The notothyrium is widely triangular, with the apical third closed by a gently convex chilidium, which continues by thin and low chilidial plates towards the hinge line.

The cardinal process is a large, broad, low ridge-like structure occupying the majority of the notothyrial chamber, halved by a low median separating ridge and bordered by low myophore ridges. The process extends from a low notothyrial platform, which extends anteriorly into a broad median ridge. The median ridge is high posteriorly, lower anteriorly and its anterior part is exaggerated by laterally adjacent proximal canals of vascula media. The anterior termination of the median ridge is fused with the low subperipheral rim. Brachiophores are short, ridge-like, widely divergent and with a short groove separating the brachiophore base from the inner socket ridge (Fig. 7L). Dorsal adductor scars are poorly impressed with a larger anterior pair placed in anteromedial position to a smaller posterior pair. The vascular system is poorly preserved, with subparallel proximal canals of vascula media divided into a very short inner branch and a long arcuate outer branch of vascula media. Vascula myaria are poorly impressed and extend between the inner and outer adductor scars.

The ventral valve outline changes from semicircular in early growth stages to subrectangular in adults, with rectangular to shortly alate cardinal extremities. The sides are evenly curved continuing into a less rounded anterior margin. The valve is from moderate to strongly convex both axially and transversally with somewhat depressed cardinal edges. The beak is short. The ventral interarea is steeply apsacline, high, gently concave, with transverse growth striation. The delthyrium is highly triangular, open and occupies some $25 \%$ of the hinge line.

Teeth are small and short, supported by a thick pad of the posterior shell wall. The dental plates are absent. The ventral muscle field is subtriangular, confined to the delthyrial chamber and occupies about $30 \%$ of the shell width and $25 \%$ of the shell length. Diductor scars are narrowly triangular, gently diverging and slightly flabellate along their anterior borders. The adductor scar is narrowly triangular, well-defined and slightly shorter than the diductor scars. The anterior part of the adductor track rests on a weakly elevated pad (Fig. 7Q). The ventral vascular system is saccate, with broad, laterally deep but axially shallow impressions of subparallel to weakly diverging proximal part vascula media. The main trunks of the vasculum media are divided into a short inner branch and a longer, arcuate and tapering outer branch of the vascula arcuata at around two-thirds of the shell length. Numerous thin radially arranged vascula terminalia extend from vascula arcuata along the majority of the shell periphery. The subperipheral rim is prominent and high in adult shells.

The ornamentation is multicostellate with uniformly sized radial costellae extending from the apex. Costellation is better developed in the dorsal valves (Fig. 7R) than the ventral valves, but this difference could be the result of surface abrasion of the ventral valve surface in all collected shells. New costellae mostly appear in front of growth lamellae. There are 2-3 costellae per $1 \mathrm{~mm}$ anteromedianly and 40-50 costellae in total on large shells. Interspaces are the same size as the costellae. Concentric ornament consists of a few weak growth lamellae, which are more crowded along the periphery of the large shells. Concentric filose ornament is very weak, being poorly preserved in all collected shells.

Remarks. - Chilidorthis tecta has been described from three localities (Havlíček \& Josopait 1972) from the fossil horizon FH 1 near the road from Ateca to Valtorres in the Iberian Chains, Spain. From an overlying level in the same area, Havlíček \& Josopait (1972) described two valves as Brahimorthis. Havlíček \& Josopait (1972) noted that the dorsal valve interior of these shells show all the diagnostic features of Brahimorthis. These features, e.g. the high convexity of the dorsal valve, absence of the cardinal process and the raised notothyrial platform, are very characteristic of the genus. Unfortunately, we were not able to successfully review the original specimens collected by Josopait, which are currently stored in the Münster University palaeontological collections. However, sampling in the same level from which Josopait originally collected the material has provided a reasonable number of new specimens. Because of the lack of illustration in Havlíček \& Josopait (1972), it is hard to judge whether there are two different brachiopod taxa or whether the attribution of two valves to Brahimorthis cf. antiqua by Havlíček \& Josopait (1972) is due to the misidentification of Chilidorthis tecta because of poor preservation. Based on our observations we suggest that the second option is more plausible. 


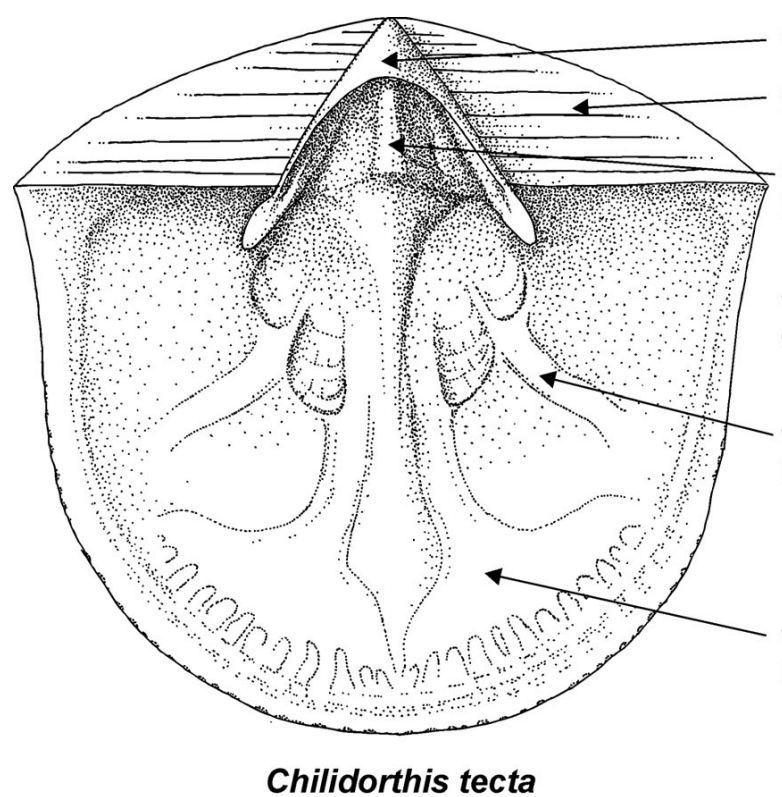

Chilidorthis tecta

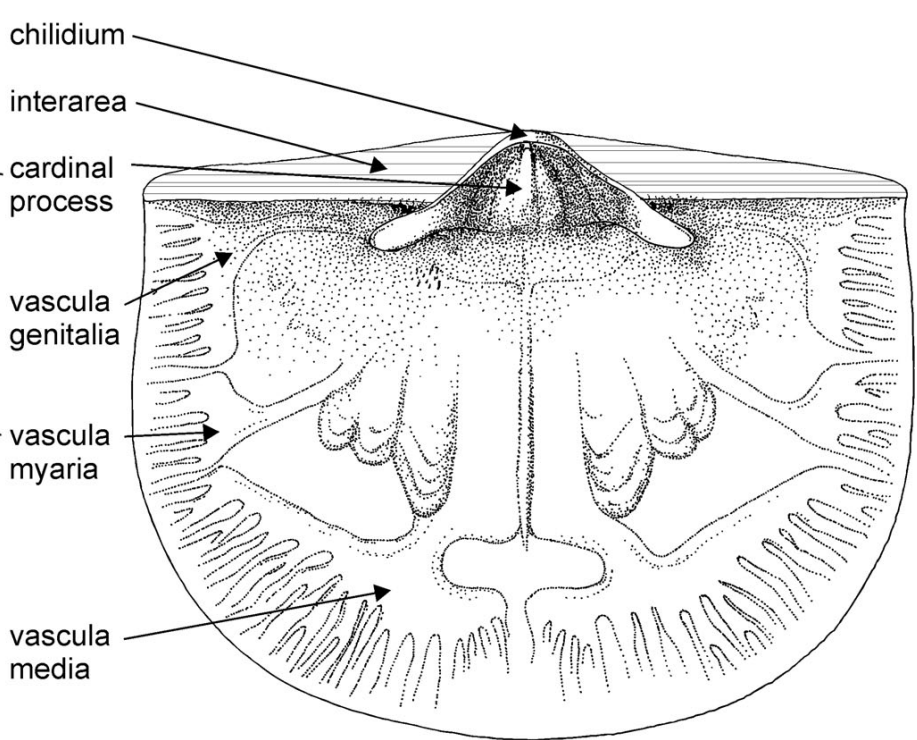

Bohemiella romingeri

Figure 8. Dorsal valve interiors of Chilidorthis tecta Havlíček \& Josopait, 1972 and Bohemiella romingeri (Barrande, 1848) with chilidia and reconstructed mantle canal systems.

Occurrence. - AT22 section, Valtorres Formation, Valtorres, Iberian Chains, Spain.

\section{General discussion}

\section{Taxonomic relationships}

The arrangement of the muscle imprints in Brahimorthis Havlíček, 1977 and Saesorthis Geyer \& Mergl, 1997 represents a synapomorphy that justifies their separation into the new family within the superfamily Orthoidea Woodward, 1931. As pointed out by Geyer \& Mergl (1997), Brahimorthis is best considered as the descendent of Saesorthis. The latter genus is known exclusively from Morocco and these authors broadly discussed its taxonomic position. Both genera share several common features: they lack dental plates and cardinal processes; have similar, highly raised delthyrial chambers which are not anteriorly extended into a distinct transverse plate; have weakly developed dental sockets and show parvicostellate ornamentation with prominent filose ornament; and have a weakly impressed vascular system. As stated by Geyer \& Mergl (1997), Brahimorthis is more derived than Saesorthis. This hypothesis is also supported by the stratigraphic ranges of both genera. Saesorthis is restricted to the Jbel Wawrmast Formation, the Hupolenus Zone and the Cephalopyge notabilis Zone of the lower middle Cambrian of Morocco. Brahimorthis occurrences in North Africa, Spain and Bohemia are younger. Brahimorthis antiqua comes originally from Jbel Wawrmast Formation of the Hassi Brahim section. The sampling level (horizon D 1887: Havlíček 1971) is uncertain but appears to be from the middle part of the middle Cambrian, corresponding with Badulesia tenera layers (Geyer \& Mergl 1997). Unnamed species of Brahimorthis (Geyer \& Mergl 1997) from Jbel Wawrmast Formation of Morocco are also mid- middle Cambrian in age. Brahimorthis cf. antiqua has been reported from the Almunia layers (Torcas Fm. after this study) in the lower part of the Iberian Series of Spain (Havlíček \& Josopait 1972) but this is most likely a misidentification. The new species of Brahimorthis alvaroi in Spain is of early middle Cambrian (lower Languedocian) age. Brahimorthis pompeckiana is known from four specimens (Havlíček 1977) which have been collected in a sandstone bank of uncertain age in the Jince area (Příbram-Jince Basin) of the Czech Republic. The now inaccessible locality has been referred to the Eccaparadoxides pusillus Zone of the Jince Formation (Fatka et al. 2004). The exact range of this zone is unknown, but likely represents the middle part of the middle Cambrian. In summary, all occurrences of Brahimorthis are thought to be from the lower to middle parts of the middle Cambrian. Only Brahimorthis alvaroi is associated with nisusiid brachiopods.

New morphological features observed in Chilidorthis tecta, especially the presence of the chilidium and observations of the chilidium of Bohemiella are in agreement with the original assigment of Chilidorthis in the Bohemiellidae by Havlíček (1977). Bohemiellia and Chilidorthis represent closely related orthids, both of which are Languedocian in age. Bohemiella romingeri is known only from the Buchava Formation, Skryje-Týřovice Basin in Central 
Bohemia (Fatka et al. 2011). Their shell morphology, distinguished by a planoconvex shell, shortly alate hinge line and fine ornament, is analogous to later Palaeozoic strophomenids. A similar mode of life and shell orientation (with the dorsal valve up) are suggested for Bohemiella and Chilidorthis.

\section{Palaeobiogeographic implications}

Current data on the morphology and distribution of rhynchonelliformean brachiopods of early to mid middle Cambrian age in Spain, Central Europe and NW Africa indicate closer phylogenetic relations between brachiopods from Bohemia (Czech Republic) and Morocco than to brachiopods from Spain: Brahimorthis pompeckiana is more closely related to $B$. antiqua than to B. alvaroi. Bohemiella was originally described from Bohemia and it is confidently known from Morocco (Geyer \& Mergl 1997), but its presence in Spain is questionable. Obollelates and kutorginates are unknown in Bohemia and this is probably a true biological signal rather than a taphonomic and/or sampling bias. Obolellates and kutorginates are common in Spain (Gil Cid \& Mélou 1986, Liñán \& Mergl 2001, Wotte \& Mergl 2007). Faunal similarities among early middle Cambrian obolellates, exemplified by the distribution of Trematobolus, exist between Spain, Morocco (Geyer \& Mergl 1995), Jordan (Richter \& Richter 1941) and Avalonian terranes (Walcott 1912, Rowell 1962). Kutorginates (Yorkia, Nisusia) are known from Spain and Avalonian terranes (Walcott 1912, Rowell 1962) but also from tropical East Gondwana (Brock 1998).

These differences are probably related to special ecological requirements of particular brachiopod groups, rather than the geographical distance of separation between Bohemia and Spain and the ability of larval migration.

Brahimorthis likely preferred the arenaceous sea floor. Bohemiella was common in finely arenaceous sea floor and had a restricted stratigraphical range. Chilidorthis likely preferred coarser arenaceous substrate and its known occurrence is also limited to a short stratigraphical interval. Obollelates and kutorginates were generally common in the lower Cambrian and extended up to the earliest middle Cambrian. Both groups preferred shallow carbonate shelves with deposition of calcarenites. In Bohemia, the shallow-water shelves with terrigenous depositions hosted mainly infaunal or epifaunal dwellers (lingulates, orthids and protorthids; Fatka et al. 2004, Mergl \& Kordule 2008) and these shelves were not suitable for occupation by the latest obollelates and kutorginates. The few known occurrences of middle Cambrian brachiopods in western Gondwana argue that all these rhynchonelliformean brachiopod dominated faunas were intimately dependent on particular arenaceous environments.

\section{Acknowledgements}

This study was supported by a grant from the Grant Agency of the Czech Republic GAČR 205/09/1521 and by the Project CGL2011-24516 from MEC of Spain. Excavations were partially financed by Gobierno de Aragón. Isabel Pérez (MEC-FSE) provided some of the photographs used in figure 3. SZ holds a Post Doctoral grant from MEC (EX2009-0815). The authors are indebted to the field assistance of Javier J. Álvaro, Jorge Colmenar, Daniel Vizcaïno and Fernando Gracia; and especially to Enrique Villas and Eladio Liñán both from the University of Zaragoza for his kind hospitality towards one of authors (MM) during his stays in Zaragoza. Imran A. Rahman (University of Birmingham) provided grammar corrections and interesting comments to an early draft of this paper.

\section{References}

Álvaro, J.J. 1995. Propuesta de una nueva unidad litoestratigráfica para el Cámbrico Medio-Superior de las Cadenas Ibéricas (NE España): el Grupo Acón. Boletín de la Real Sociedad Española de Historia Natural (Sección Geológica) 90, 95-106.

Álvaro, J.J. \& Vizcaïno, D. 1998. Révision biostratigraphique du Cambrien moyen du versant méridional de la Montane Noire (Languedoc, France). Bulletin de la Société Géologique de France 169, 233-242.

Álvaro, J.J., Bauluz, B., Pierre, C., Subías, I. \& Vizcaïno, D. 2008. Carbon chemostratigraphy of the Cambrian-Ordovician transition in a midlatitude mixed platform, Montagne Noire, France. Geological Society of America Bulletin 120, 962-975. DOI 10.1130/B26243.1

BELL, W. 1941. Cambrian Brachiopoda from Montana. Journal of Paleontology 15, 193-255.

Bergeron, J. 1889. Etude géologique du Massif situé au sud du plateau central. Annales de la Société Géologique du Nord 22, $1-362$.

BiLlings, E. 1861. On some new or little known species of lower Silurian fossils from the Potsdam Group (Primordial zone). Palaeozoic fossils, Vol. 1, No. 1. 18 pp. Canadian Geological Survey, Dawson Borthers, Montreal.

Brock, G. 1998. Middle Cambrian articulate brachiopods from the Southern New Eangland fold belt, Northeastern N.S.W., Australia. Journal of Paleontology 72(4), 604-619.

Clausen, S. \& Álvaro, J.J. 2006. Skeletonized microfossils from the Lower-Middle Cambrian transition of the Cantabrian Mountains, northern Spain. Acta Palaeontologica Polonica 51, 223-238.

Esteve, J., Hughes, N.C. \& Zamora, S. 2011. Purujosa trilobite assemblage and evolution of trilobite enrollment. Geology 39(6), 575-578. DOI 10.1130/G31985.1

Geyer, G. \& Mergl, M. 1995. Mediterranean representatives of the obolellid Trematobolus Matthew (Brachiopoda) and a review of the genus. Paläontologische Zeitschrift 69(12), 179-209.

Geyer, G. \& Mergl, M. 1997. Protorthacean Brachiopods from the Middle Cambrian of Morocco. Journal of Paleontology 71(5), 791-812. 
Gil Cid, M.D. \& Melou, M. 1986. Brachiopodes du Cambrien moyen de Zafra (Province de Badajoz, Espagne). Géologie Méditerranéenne 12-13, 197-205.

Gozalo, R., Chirivella Martorell, J.B., Esteve, J. \& Liñán, E. 2011. Correlation between the base of Drumian Stage and the base of middle Caesaraugustan Stage in the Iberian Chains (NE Spain). Bulletin of Geosciences 86, 545-554. DOI 10.3140/bull.geosci.1254

Gozalo, R., LiÑÁn, E. \& Álvaro, J. 1994. Trilobites de la Subfamilia Solenopleuropsinae Thoral, 1947 del Cámbrico medio de la unidad de Alconera. Boletín de la Real Sociedad Española de Historia Natural, Sección Geológica $89,43-54$

HavlíčEK, V. 1970. Pompeckium and Jamesella (Orthacea, Brachiopoda) in the Middle Cambrian of Bohemia. Věstník Ústředního ústavu geologického 45(5), 289-290.

HAVlíčEK, V. 1971. Brachiopodes de l'Ordovicien du Maroc. Notes et mémoires du Service géologique du Maroc 230, $1-135$.

HAVLÍčEK, V. 1977. Brachiopods of the order Orthida in Czechoslovakia. Rozpravy Ústředního ústavu geologického 44, $1-327$.

HAVLíčEK, V. \& Josopait, V. 1972. Articulate brachiopods from the Iberian Chains, Northern Spain (Middle Cambrian - Upper Cambrian - Tremadoc). Neues Jahrbuch für Geologie und Paläontologie, Abhandlungen 140, 328-353.

JAEKel, O. 1918. Phylogenie und System der Pelmatozoen. Paläontologische Zeitschrift 3, 1-128.

Josopait, V. 1972. Das Kambrium und das Tremadoc von Ateca (Westliche Iberische Ketten, NE-Spanien). Münstersche Forschungen zur Geologie und Paläontologie 23, 1-121.

Kobayashi, T. 1935. The Cambro-Ordovician shelly faunas of South Chosen. Journal of the Faculty of Science, Imperial University of Tokyo, Section II (Geology, Mineralogy, Geography, Seismology) 4(2), 49-344.

Kruse, P.D. 1990. Cambrian palaeontology of the Daly Basin. Northern Territory Geological Survey, Report 7, 1-58.

Kunn, O. 1949. Lehrbuch der Paläozoologie. 326 pp. Schweizerbart, Stuttgart.

LiÑán, E. \& GoZALO, R. 1986. Trilobites del Cámbrico Inferior y Medio de Murero (Cordillera Ibérica). Memorias del Museo Paleontológico de la Universidad de Zaragoza 2, 1-104.

Liñán, E. \& Mergl, M. 2001. Lower and Middle Cambrian brachiopods from the Iberian Chains and Sierra Morena (Spain). Revista Española de Paleontologia 16, 317-337.

Liñán, E., Perejón, A. \& Sdzuy, K. 1993. The Lower-Middle Cambrian stages and stratotypes from the Iberian Peninsula: a revision. Geological Magazine 130, 817-833. DOI 10.1017/S0016756800023189

Matthew, G.F. 1893. Trematobolus. An articulate brachiopod of the inarticulate order. The Canadian Record of Science 5, 276-270.

Mergl, M. 1983. New brachiopods (Cambrian-Ordovician) from Algeria and Morocco (Mediterranean Province). Časopis pro mineralogii a geologii 28(4), 337-348.

Peng, S.C. \& BABCOCK, L.E. 2011. Continuing progress on chronostratigraphic subdivision of the Cambrian System. Bulletin of Geosciences 86(3), 391-396.

DOI 10.3140/bull.geosci.1273
Prado, C. de, Verneuil, E. de \& Barrande, J. 1860. Sur l'existence de la faune primordiale dans la chaîne cantabrique. Bulletin de la Société géologique de France, 2 série, 17, 516-554.

Roberts, J. \& Jell, P.A. 1990. Early Middle Cambrian (Ordian) brachiopods of the Coonigan Formation, western New South Wales. Alcheringa 14, 257-309.

DOI 10.1080/03115519008619059

RowelL, A.J. 1962. The genera of the brachiopod superfamilies Obolellacea and Siphonotretacea. Journal of Paleontology 36, 136-152.

SAMPELAYO, P.H. 1935. Explicación del nuevo mapa geológico de España en escala 1:1.000.000. El Sistema Cambriano. Memorias del Instituto Geológico y Minero de España 1, 291-525.

Schuchert, C. \& Cooper, G.A. 1931. Synopsis of the brachiopod genera of the suborder Orthoidea and Pentameroidea, with notes on the Telotremata. American Journal of Sciences (series 5) 22, 241-255.

SDZuY, K. 1958. Neue Trilobiten aus dem Mittelkambrium von Spanien. Senckenbergiana lethaea 39(3-4), 235-253.

SherGold, J.H. \& SDzuy, K. 1991. Late Cambrian trilobites from the Iberian Mountains, Zaragoza Province, Spain. Beringeria 4, 193-235.

Ubaghs, G. 1987. Echinodermes nouveaux du Cambrien moyen de la Montagne Noire (France). Annales de Paléontologie 73, $1-27$.

WalcotT, C.D. 1897. Cambrian Brachiopoda: Genera Iphidea and Yorkia, with descriptions of new species of each, and of the genus Acrothele. United States National Museum, Proceedings 19(1120), 707-718.

WalcotT, C.D. 1905. Cambrian Brachiopoda with descriptions of new genera and species. Proceedings of the Unites States National Museum 28, 227-337. DOI 10.5479/si.00963801.1395.227

WALCOTT, C.D. 1908. Cambrian geology and paleontology. No. 3. Cambrian Brachiopoda, descriptions of new genera and species. Smithsonian Miscellaneous Collections 53, 53-165.

WALCOTT, C.D. 1908. Cambrian geology and paleontology. No. 4. Classification and terminology of the Cambrian Brachiopoda. Smithsonian Miscellaneous Collections 53, 53-137.

WALcotT, C.D. 1912. Cambrian Brachiopoda. United States Geological Survey Monograph 51, 1-872.

Williams, A. \& HARPER, D.A.T. 2000. Orthida, 714-782. In WILLiams, A., BRunton, C.H.C., CARLSON, S.J. et al. Treatise on Invertebrate Paleontology, part $H$, Brachiopoda, Revised, Volume 3. Geological Society of America, Inc. \& University of Kansas Press, Boulder, Colorado \& Lawrence, Texas.

Woodward, S.P. 1851-1856. A Manual of the Mollusca. 488 pp. John Weale, London.

Wotte, T. 2006. New Middle Cambrian molluscs from the Láncara Formation of the Cantabrian Mountains (northwestern Spain). Nuevos moluscos de la Formación Láncara, Cámbrico Medio de la Cordillera Cantábrica (Noroeste de España). Revista Española de Paleontología 21, 145-158.

Wotte, T. \& Mergl, M. 2007. Brachiopods from the LowerMiddle Cambrian Láncara Formation of the Cantabrian Mountains, Northwest Spain. Memoirs of the Association of Australasian Palaeontologists 33, 101-122. 
Yuan, J.L., Zhu, X.J., Lin, J.P. \& Zhu, M.Y. 2011. Tentative correlation of Cambrian Series 2 between South China and other continents. Bulletin of Geosciences 86(3), 397-404.

DOI 10.3140/bull.geosci.1274

Zamora, S. 2009. Equinodermos del Cámbrico medio de las Cadenas Ibéricas y de la Zona Cantábrica (Norte de España). 307 pp. Unpublished Ph.D. thesis, Universidad de Zaragoza, Spain.

Zamora, S. 2010. Middle Cambrian echinoderms from North Spain show echinoderms diversified earlier in Gondwana. Geology 38, 507-510. DOI 10.1130/G30657.1

ZAMORA, S. \& Álvaro, J.J. 2010. Testing for a decline in diversity prior to extinction: Languedocian (latest Mid-Cambrian) distribution of Cinctans (Echinodermata) in the Iberian Chains, NE Spain. Palaeontology 53, 1349-1368. DOI 10.1111/j.1475-4983.2010.01004.x

Zamora, S., Mayoral, E., Esteve, J., Gámez Vintaned, J.A. \& SAntos, A. 2011. Exoskeletal abnormalities in paradoxidid trilobites from the Cambrian of Spain, and a new type of bite trace. Bulletin of Geosciences 86(3), 665-673.

DOI 10.3140/bull.geosci.1275

Zamora, S. \& Sмith, A.B. 2008. A new Middle Cambrian stem-group echinoderm from Northeast Spain: Taxonomy, palaeoecology and palaeogeographic implications. Acta Palaeontologica Polonica 54, 253-295.

DOI 10.4202/app.2008.0010

Zamora, S. \& Smith, A.B. 2010. The oldest isorophid edrioasteroid (Echinodermata) and the evolution of attachment strategies in Cambrian edrioasteroids. Acta Palaeontologica Polonica 55, 487-494.

DOI 10.4202/app.2010.0012

Zamora, S. \& Smith, A.B. 2012. Cambrian stalked echinoderms show unexpected plasticity of arm construction. Proceedings of The Royal Society B 279, 293-298.

DOI 10.1098/rspb.2011.0777 